\title{
Traditional Techniques Applied in Olive Oil Production Results in Lower Quality Products in Northern Cyprus
}

\section{Kuzey Kıbrıs'ta Zeytinyağı Üretiminde Kullanılan Geleneksel Yöntemler Daha Düşük Kaliteli Ürünler Oluşturmaktadır}

\author{
(D) Amirhossein FALLAH ${ }^{1}$, (D) Hayrettin Ozan GÜLCAN ${ }^{1 *}$, (D) Canan GÜLCAN¹, (D) Tuğba ERÇETiN¹, (D) Seray KABARAN², (D) Imge KUNTER1, \\ (D) Mustafa GAZi ${ }^{3}$, (D) Gönül ŞAHIN', (D) Mustafa Fethi ŞAHIN ${ }^{1}$ \\ 'Eastern Mediterranean University, Faculty of Pharmacy, Famagusta, Northern Cyprus \\ 2Eastern Mediterranean University, Faculty of Health Sciences, Department of Nutrition and Dietetics, Famagusta, Northern Cyprus \\ ${ }^{3}$ Eastern Mediterranean University, Faculty of Art and Sciences, Department of Chemistry, Famagusta, Northern Cyprus
}

\begin{abstract}
Objectives: Olive oil production and its consumption is one of the traditional characteristics of Northern Cyprus. To date, no research has been conducted to analyze the quality of traditionally produced olive oil. Therefore, within this study, we aimed to analyze the olive oil produced within the island concomitant to the determination and comparison of its quality indices.

Materials and Methods: The standard olive oil analysis techniques acknowledged by the IOOC and ISO were employed. Accordingly, the fatty acid content, peroxide level, total phenol content, the levels of carotenoids and chlorophyll, as well as status of oxidation were all tested concomitant to statistical analysis.

Results: In contrast to the regional belief and consideration, the results indicated that the olive oil produced locally is highly exposed to oxidation and therefore, it is of lower quality according to the ISO guidelines.

Conclusion: The traditional techniques employed for the production, distribution, and storage of olive oil within Northern Cyprus must be reevaluated and controlled to satisfy the current standards required and employed globally.
\end{abstract}

Key words: Olive oil, analysis, oxidation, Northern Cyprus

Öz

Amaç: Zeytinyağı üretimi ve tüketimi Kuzey Kıbrıs'ın geleneksel özelliklerinden biridir. Şu ana kadar, bu geleneksel olarak üretilen zeytinyağının kalitesini analiz etmek için yapılan bir bilimsel araştırma çalışması bulunmamaktadır. Bu nedenle, bu çalışmada, adada üretilen zeytinyağını analiz ederek kalite endekslerinin belirlenmesini ve karşılaştırıımasını amaçladık.

Gereç ve Yöntemler: IOOC ve ISO tarafından onaylanan standart zeytinyağı analiz teknikleri kullanılmıştır. Buna göre, yağ asiti içeriği, peroksit seviyesi, toplam fenol içeriği, karotenoidler ve klorofil seviyeleri ve oksidasyon durumu istatistiksel analizlere paralel olarak analiz edilmiştir.

Bulgular: Zeytinyağının Kuzey Kıbrıs'taki üretimi, dağııımı ve depolanması için kullanılan geleneksel teknikler, global düzeyde ortaya konulan standartları karşılamak üzere yeniden değerlendirilmeli ve kontrol edilmelidir.

Sonuç: Bölgesel inanç ve değerlendirmenin aksine, sonuçlar, yerel olarak üretilen zeytinyağının oksidasyona aşırı derecede maruz kaldığını ve dolayısıyla ISO talimatlarına göre daha düșük kalitede olduğunu ortaya koymuștur.

Anahtar kelimeler: Zeytinyağı, analiz, oksidasyon, Kuzey Kıbrıs

*Correspondence: E-mail: ozan.gulcan@emu.edu.tr, Phone: +90 5338370025 ORCID-ID: orcid.org/0000-0002-9503-5841

Received: 21.04.2017, Accepted: 22.06.2017

๑Turk J Pharm Sci, Published by Galenos Publishing House. 


\section{INTRODUCTION}

There is no doubt that olive oil consumption has been a significant component of the daily diet in the Mediterranean region. Indeed, olive tree (Olea europea L.) agriculture, and the following olive oil production is typical and one of the oldest traditions in various countries in the region., ${ }^{1,2}$ Starting from the second half of the last century, the adoption of the Mediterranean diet in non-Mediterranean areas has led to the production of olive oil in higher amounts to respond to the worldwide demand which, in turn, has forced the establishment of industrialization for olive oil production to guarantee quality. 3,4 This has further been regulated and warranted by both the producer countries and the International Organization for Standardization. ${ }^{5-7}$

As a part of Cyprus, Northern Cyprus, also referred to as the Turkish Republic of Northern Cyprus, in the middle of the Mediterranean Sea, is one of those countries continuing to harvest thousands of tons of olive fruit and olive oil annually. Even archaeologic ruins from the Neolithic period (8200 BC) in the region indicate the processing of olive fruits since that time. ${ }^{8}$ Records currently estimate the presence of approximately 1 million olive trees (Olea europea L.), many of which are cultivated to obtain olive fruits (i.e., a typical breakfast diet), and olive oil.9 Furthermore, current data also indicate that olive oil consumption per person is around $25-50 \mathrm{~mL} /$ day in the region. ${ }^{10}$ Indeed, almost all of the local restaurants in the region serve olive oil as one of the appetizers, even without charge.

Besides the existence of a few producers that use modern industrial subsidiaries, the majority employs traditional methods for olive oil production in Northern Cyprus. In public, these techniques are classified as either hot or cold procedures. As implied, cold and hot refers to the temperature in the extraction phase (i.e., a lower than $28^{\circ} \mathrm{C}$ aqueous phase for the cold procedure and an above $28^{\circ} \mathrm{C}$ aqueous phase for the hot procedure). It is considered that the hot procedure accelerates the extraction phase, therefore aids in the yield and stability with respect to the time spent. On the other hand, it is a disadvantage for the transfer of various beneficial chemicals (e.g., stabilizers, and antioxidants) to the aqueous phase depending on the change of solubility at varying temperatures.11-13 Moreover, the majority of the public rely on olive oil products produced through traditional techniques rather than industrial products because they consider it more natural. The industrial local products are generally produced for export to other countries concomitant to analysis certificates guaranteeing the quality, whereas almost all of the local traditionally produced products reach consumers, even without an apparent label. The main difference with the current traditional techniques is that they do not obey the manufacturing rules strictly regulated in the industrialized techniques. The exposure to air and light during the production phase, the non-employment of protective equipment or systems to prevent oxidation and the related degeneration of olive oil, as well as the inadequate containers used (e.g., non-opaque glass material without a correct label) make the traditionally produced olive oils susceptible. Some producers still use stone-mills for malaxation.
To date, no scientific research has been conducted to screen the quality indices of traditionally produced olive oil in Northern Cyprus. From this point of view, this research aimed to investigate, for the first time, the basic quality parameters of the olive oil produced employing the traditional techniques within Northern Cyprus. Therefore, the quality indices [i.e., free fatty acid (FFA) percentage, peroxide value (PV), ultraviolet (UV)-specific extinctions at 232 and $272 \mathrm{~nm}$, total phenol, chlorophyll, and carotenoid contents, and fatty acid alkyl ester (FAAEs) compositions] of the samples collected.

\section{MATERIALS and METHODS}

\section{Chemicals and reagents}

Hexane (99.0\%), cyclohexane (99.5\%), ethanol (99.9\%), methanol (99.9\%), diethyl ether (99.0\%), sodium carbonate, sodium thiosulfate, potassium hydroxide (85.0\%), potassium iodide (99.0\%), sodium hydroxide (99.0\%), acetic acid $(99.0 \%)$, hydrochloric acid (37\%), gallic acid were obtained from Merck (Germany). Folin-coicalteus phenol was purchased from Sigma-Aldrich (Darmstadt, Germany).

\section{Samples}

Although there are quite a number of producers, particularly within the western part of the region, the majority produce limited amounts for their own use. Therefore, we collected olive oil samples from the thirteen olive oil producers who sell their traditionally produced olive oils besides having it for their own use. From this point of view, 26 samples in capped non-opaque glass materials (i.e., the classic way of packing and marketing of producers) from 13 different producers were purchased directly from the producers (i.e., 2 samples from the same production of the same producer). Each sample from 13 producers was subcategorized in such a way that the first group was analyzed in their $3^{\text {rd }}$ month of production, and the second group would be analyzed in their 6 month of production. The samples to be analyzed in these periods were kept in light-free shelves at room temperature until analysis. In order to make a comparison with a reference product from industrial production, a commercial extra virgin olive oil from the $3^{\text {rd }}$ month of its production (the data on the label was used directly) was also purchased from a supermarket and employed in the same analysis. Each sample was analyzed three times and the results are expressed as mean \pm standard deviation. Table 1 shows the codes, the place obtained, and the production method (i.e., cold or hot) of the samples analyzed.

\section{Determination of FFA content}

FFA, expressed as the percentage content of the FFA in olive oil, was determined through titration using potassium hydroxide according to the proposed procedure by IS0660.14 Accordingly, a 500-mg olive oil sample was dissolved in $15 \mathrm{~mL}$ of ethanol and diethyl ether (solvent mixture), which was previously neutralized using potassium hydroxide. This solution was then titrated with $0.1 \mathrm{~N}$ potassium hydroxide. Acidity, expressed as a percentage of fat type, was calculated according to the given formula: 
Acidity $=(\mathrm{V} \times \mathrm{N} \times \mathrm{F} \times \mathrm{M}) /(10 \times \mathrm{m})$

wherein:

$\mathrm{V}=$ The volume of $0.1 \mathrm{~N} \mathrm{KOH}$ consumed,

$\mathrm{F}=$ Factor of $0.1 \mathrm{~N} \mathrm{KOH}$,

$\mathrm{N}=$ Normality of $\mathrm{KOH}$ (i.e., 0.1),

$M=$ Molar mass of oil in gram per mole (i.e., $256 \mathrm{~g} / \mathrm{mol}$ ) and, $\mathrm{m}=$ the mass in gram of the test portion.

\section{Assessment of PV}

$\mathrm{PV}$, as stated in milliequivalent of $\mathrm{O}_{2} \cdot \mathrm{kg}^{-1}$ (meq $\mathrm{O}_{2} / \mathrm{kg}$ oil), was determined according to the method described by ISO3960.15 Briefly, a 5-g olive oil sample was dissolved in glacial acetic acid-hexane (6:4) solution. Then, $0.5 \mathrm{~mL}$ of saturated potassium iodide was added and swirled for exactly one min. Immediately after, $100 \mathrm{~mL}$ distilled water was introduced to the flask and shaken vigorously. Finally, the mixture was titrated with $0.01 \mathrm{~N}$ sodium thiosulfate. $\mathrm{PV}$ ( $\mathrm{meqO}_{2} / \mathrm{kg}$ oil) was calculated based on the formula described below:

$P V=\left[\left(V-V_{0}\right) \times N \times F \times 1000\right] / m$

wherein;

$\mathrm{V}$ : The volume of sodium thiosulfate consumed for the sample,

$V_{0}$ : The volume of sodium thiosulfate consumed for the titration of the blank (without olive oil sample),

$\mathrm{N}$ : The normality of sodium thiosulfate (i.e., $0.01 \mathrm{~N}$ ), and, $\mathrm{m}$ : Mass (weight) of sample in gram.

Determination of oxidation status of olive oils ( $K 232$ and K270) The experiment to determine the oxidation status of olive oils was performed by measuring their absorption at specific wavelengths (i.e., 232 and $270 \mathrm{~nm}$ ). ${ }^{16}$ In brief, $0.25 \mathrm{~g}$ olive oil sample was dissolved in cyclohexane in a $25 \mathrm{~mL}$ graduated flask to prepare $1 \% \mathrm{w} / \mathrm{v}$. Then, the specific extinctions at 232 and $270 \mathrm{~nm}$ were examined.

\section{Carotenoids and chlorophyll content assays}

Carotenoid and chlorophyll (mg/kg of oil) contents were determined employing a UV-based procedure. ${ }^{17}$ As described above, a 0.25 -g olive oil sample was dissolved in cyclohexane (i.e., $1 \% \mathrm{w} / \mathrm{v}$ ) and the specific extinctions were determined at 470 and $670 \mathrm{~nm}$, respectively, for the carotenoid and chlorophyll contents.

\section{Detection of total phenol content (TPC)}

The Folin-Ciocalteu method, an assay in which the results are expressed in terms of gallic acid as $\mathrm{mg}$ of gallic acid/ $\mathrm{kg}$ olive oil depending on the spectrophotometric measurements conducted at $765 \mathrm{~nm}$, was employed for the determination of the TPC. ${ }^{18}$ Accordingly, $10 \mathrm{~g}$ of olive oil was dissolved in 50 $\mathrm{mL}$ of hexane and extracted three times with $80 \%$ aqueous methanol. The extract was then added to distilled water to a final volume of $100 \mathrm{~mL}$ aqueous methanol and kept overnight. Five milliliters of Folin-Ciocalteu phenol reagent was added to $1 \mathrm{~mL}$ of aliquot extract, then shaken well and left to stand for 5 min. One milliliter of saturated sodium carbonate was added and swirled. After 1 hour at room temperature, absorption was read at $765 \mathrm{~nm}$. A one milliliter aliquot of $0.05,0.2,0.4,0.5$, and $0.6 \mathrm{mmol} / \mathrm{L}$ aqueous gallic acid solutions were mixed with $5 \mathrm{~mL}$ Folin-Ciocalteu reagent and $1 \mathrm{~mL}$ saturated sodium carbonate solution. Absorption was measured at $725 \mathrm{~nm}$ to obtain the calibration curve. Finally, the total concentration of polyphenol in the olive oil samples was determined as ppm of Gallic acid.

\section{Determination of FAAEs}

For the determination of FAAEs, the European Official Methods of Analysis, suggesting a GC assay, was used. ${ }^{19}$ Accordingly, a $100-\mathrm{mg}$ olive oil sample was dissolved in $10 \mathrm{~mL} \mathrm{n}$-hexane in a $20-\mathrm{mL}$ test tube and $100 \mu \mathrm{L}$ of $2 \mathrm{~N}$ potassium hydroxide in methanol was added. The prepared sample solution was vortexed for 30 seconds and centrifuged for $15 \mathrm{~min}$. Afterwards, the supernatant phase was transferred into a 2-mL autosampler vial for chromatographic analysis.

Chromatographic analyses were performed on an Agilent 6890 GC (Agilent Technologies, Santa Clara, USA) fitted with an FID detector. The column used was a capillary HP-88 J\&W 11288A7 (length $100 \mathrm{~m}$, id $0.25 \mathrm{~mm}$ and film thickness $0.2 \mu \mathrm{m}$ ). The operating conditions were as follows: the inlet temperature was $250^{\circ} \mathrm{C}$; injection volume was $2 \mu \mathrm{L}$; the carrier gas was helium with a flow rate of $2 \mathrm{~mL} / \mathrm{min}$ and 1:50 split ratio; oven temperature was set to $120^{\circ} \mathrm{C}$ for $1 \mathrm{~min}$ initially, and then it was first increased up to $175^{\circ} \mathrm{C}$ (i.e., $10^{\circ} \mathrm{C} / \mathrm{min}$ rate), then increased to $220^{\circ} \mathrm{C}$ (i.e., $3^{\circ} \mathrm{C} / \mathrm{min}$ rate), where it was maintained for $5 \mathrm{~min}$; the detector temperature was set to $280^{\circ} \mathrm{C}$.

\section{Statistical analysis}

Statistical analysis was performed using the SPSS 20.0 software package (SPSS Inc., Chicago, IL, USA). Mean scores and standard deviations were calculated with respect to the assay results practiced in triplicate. The paired-samples t-test was employed in order to show the statistical significance between the mean scores of the 3 and 6 months samples.

\section{RESULTS AND DISCUSSION}

In order to determine the basic quality indices of the samples collected, the percent free acid, PVs, and the specific absorption coefficients were measured first. The results obtained for the percent free acid of the samples and the reference are shown in Figure 1. The IOOC defines and designates the classification of olive oil mainly according to their FFA content. ${ }^{20}$ Accordingly, none of the three month samples can be classified as extra virgin olive oil. Each was categorized as virgin olive oil because the results for the free acid content for each 3 month sample was found less than 2 grams per 100 grams oil. With respect to the FFA content in the 6 month samples, the categorization as virgin olive oil was saved for the majority of the samples, although 2 of them (i.e., 50, and 60, both of which were cold procedure products) appeared to be ordinary virgin olive oil according to the IOOC guidelines. Furthermore, the reference commercial sample was shown to keep its extra virgin olive oil property in the first 6 months following its production. It is noteworthy that the increase in percent FFA content in each sample and the reference was found statistically significant (i.e., p<0.05). 
One of the major parameters that shows the quality of olive oil is the PV, defined as the measure of total peroxides in olive oil expressed as milliequivalent of $\mathrm{O}_{2} / \mathrm{kg}$ oil. The upper standard for the peroxide is $20 \mathrm{meq} / \mathrm{kg}$ oil. ${ }^{21,22}$ Besides sample $11 \mathrm{~F}$, each sample was shown to possess peroxide levels less than the upper standard in the $3^{\text {rd }}$ month analysis (i.e., Figure 2). However, there was a serious increase in terms of $P V$, an indication of oxidation in all of the samples tested. Indeed, more than half of the samples tested $(10,20,40,50,60,70$, 100 , and 110) were shown to have peroxide levels less than 20 $\mathrm{meq} / \mathrm{kg}$ oil in their 6 month analysis. Besides sample 30 , all of the cold procedure products were found to possess a higher tendency for oxidation. The increase in the PV for the reference sample was also established; however, it did not reach the upper standard peroxide level (i.e., $20 \mathrm{meq} / \mathrm{kg}$ oil), even at the $6^{\text {th }}$ month. Moreover, the increase observed for the PV of each sample, including the reference, was found statistically significant (i.e., p <0.05). The oxidation status of each sample was also analyzed in other experiments.

The measurement of absorptions at $232 \mathrm{~nm}$ (i.e., $\mathrm{K}_{232}$ ) and 270 $\mathrm{nm}$ (i.e., $\mathrm{K}_{270}$ ) are important parameters for the estimation of the oxidation stage of olive oil. The increase in the number of conjugated diene and trienes contribute to $\mathrm{K}_{232}$, and the secondary oxidation resulting in the formation of aldehydes and ketones is effective for $\mathrm{K}_{270}{ }^{23}$ The European Regulation standard limit value for olive oil expresses $K_{232} \leq 2.5$ for extra virgin olive oil and $K_{232} \leq 2.6$ for both virgin olive oil and ordinary olive oil. On the other hand, $K_{270}$ values are restricted to $\leq 0.2$ for extra virgin olive oil and $\leq 0.25$ for both virgin olive oil and ordinary olive oil.. ${ }^{24}$ As seen in Figure 3, all of the samples, regardless of their analysis time and extraction procedure, had $\mathrm{K}_{232}$ levels less than 2.5. However, it is obvious that there was an increase in $\mathrm{K}_{232}$ levels from the $3^{\text {rd }}$ to $6^{\text {th }}$ month samples, making the $\mathrm{K}_{232}$ levels become closer to the upper limit of 2.5, and 2.6 for the extra virgin olive oil, virgin olive oil, and ordinary olive oil, respectively. On the other hand, the $\mathrm{K}_{270}$ measurements in the

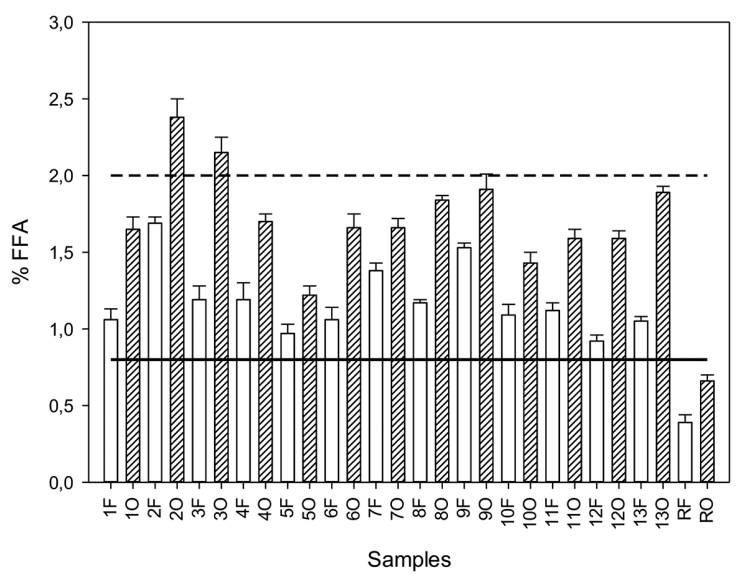

Figure 1. Percent free fatty acid of the samples and reference

$F, O$, and $R$ represent 3 months, 6 months, and reference samples, respectively. The solid and the dashed lines indicate the highest levels for the free acid content of the extra virgin olive oil, and the virgin olive oil, respectively

FFA: Free fatty acid
3 month samples classified almost all of the samples (besides sample 9F) under the extra virgin olive oil quality (i.e., Figure 4). However, similar to the observation obtained for the $\mathrm{K}_{232}$ values, all of the samples tested in their $6^{\text {th }}$ month obviously indicated an increase, all above 0.25. This is an absolute indication of oxidation as determined in UV studies (i.e., $\mathrm{K}_{232}$ and $\mathrm{K}_{270}$ measurements) concomitant to the results obtained for the peroxide measurements. Besides the $K_{232}$ value change for the samples 2 (i.e., $2 \mathrm{~F}$ and 20 ), and 4 (i.e., $4 \mathrm{~F}$ and 20 ) and $K_{270}$ value changes for the samples 5 (i.e., $5 F$ and 50), and 9 (i.e., $9 \mathrm{~F}$ and 90), and the reference, all changes for the rest of the samples were found to be statistically significant (i.e., p<0.05).

Phenolic compounds are also present in olive oil. They are important for biologic systems with respect to their antioxidant capacity and have significant parameters that show the level of

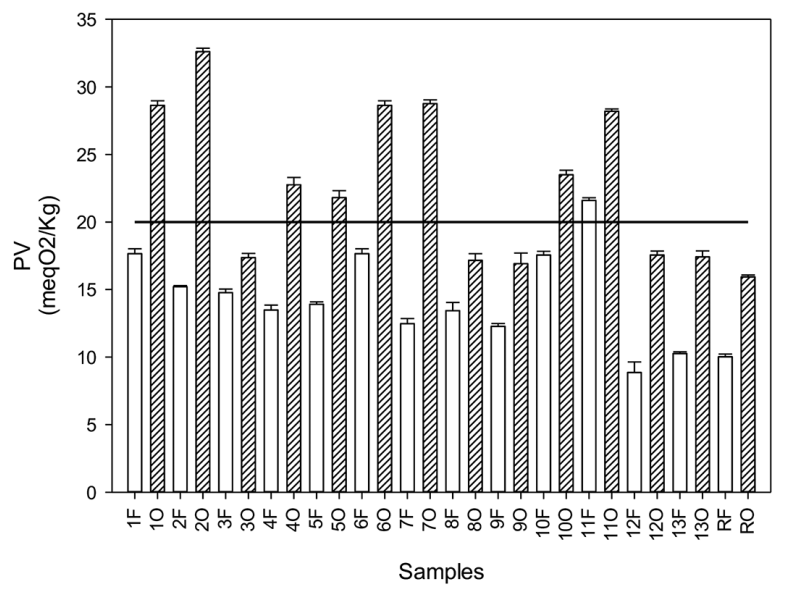

Figure 2. Peroxide value of the samples and reference

F, O, and R represent 3 months, 6 months, and reference samples, respectively. The solid line indicates the upper standard for the peroxide level PV: Peroxide value

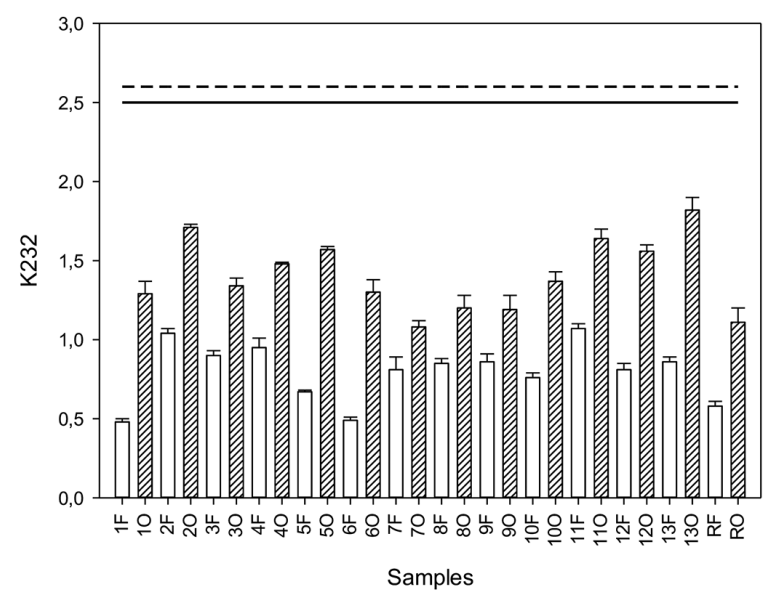

Figure 3. $\mathrm{K}_{32}^{2}$ level of the samples and reference

F, $\mathrm{O}$, and $\mathrm{R}$ represent 3 months, 6 months, and reference samples, respectively. The solid line, and the dashed lines indicate the upper standards respectively for the extra virgin olive oil, and virgin olive oil 
oxidation in olive oil. ${ }^{25,26}$ According to the results we obtained for the TPCs of the samples (i.e., Figure 5), it was obvious that the TPC of the samples were quite low in comparison with the industrially produced reference olive oil product in both $3^{\text {rd }}$ and $6^{\text {th }}$ month analyses. Furthermore, hot and cold extraction techniques made no difference in terms of the presence of phenolic compounds because both techniques' products had a TPC ranging around $70 \mathrm{ppm}$ to a very low $10 \mathrm{ppm}$. This implies that the missing control systems in the production of traditionally produced olive oils (e.g., high exposure to light and air) and the inadequacy of the packaging resulted in oxidation of phenolic compounds. This is totally consistent with previous results obtained in previous experiments (i.e., PV values,

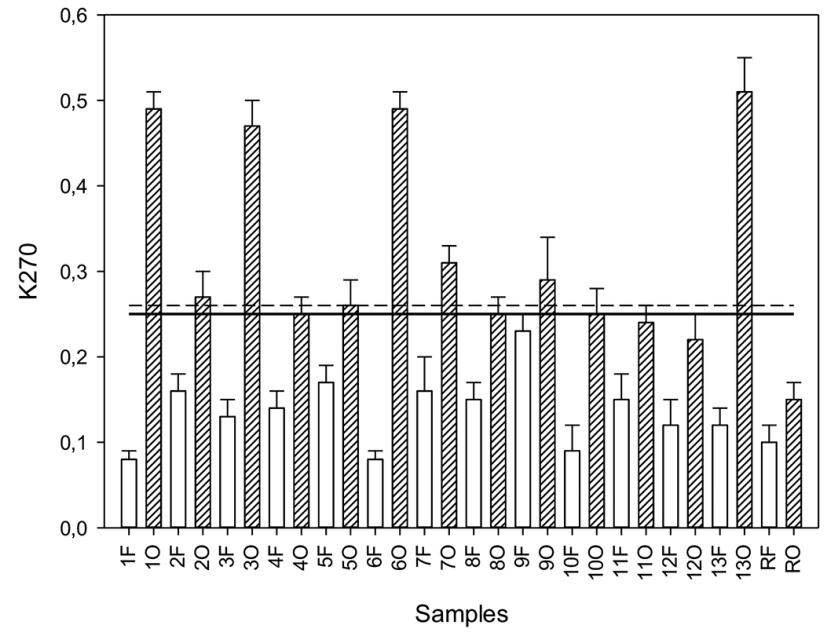

Figure 4. $\mathrm{K}_{270}$ level of the samples and reference

F, O, and R represent 3 months, 6 months, and reference samples, respectively. The solid line, and the dashed lines indicate the upper standards respectively for the extra virgin olive oil, and virgin olive oil

Table 1. The origin, extraction type, and the coding of the olive oil samples employed

\begin{tabular}{lll}
\hline Code & Place of origin & Extraction type \\
\hline 1 & Bostanci (Zodia) & Cold \\
\hline 2 & Camlikoy (Camlikoy) & Cold \\
\hline 3 & Yesilirmak (Limnidi) & Cold \\
\hline 5 & Yesilirmak (Limnidi) & Cold \\
\hline 6 & Guzelyurt (Morphou) & Cold \\
\hline 7 & Guzelyurt (Morphou) & Cold \\
\hline 8 & Yedidalga (Potamos du Gambo) & Hot \\
\hline 9 & Yedidalga (Potamos du Gambo) & Hot \\
\hline 10 & Yedidalga (Potamos du Gambo) & Hot \\
\hline 11 & Yesilyurt (Pentagia) & Hot \\
\hline 12 & Yesilyurt (Pentagia) & Hot \\
\hline 13 & Yesilyurt (Pentagia) & Hot \\
\hline
\end{tabular}

$\mathrm{K} 232$, and K270 measurements) displaying the high exposure of samples to oxidation. It is also clear that the decrease in TPC was also found statistically significant for each sample, including the reference (i.e., p<0.05). In contrast to the regional belief of the public, this status also questions the nutritional level of the olive oil produced under primitive conditions without the presence of industrialized systems. The percent FFA, peroxide, and $\mathrm{K}_{232}$ and $\mathrm{K}_{270}$ measurements of the samples and the reference concomitant to statistical analyses are provided in detail in Table 2.

Besides their function for coloration, pigment contents (i.e., chlorophylls and carotenoids) present in olive oil are critical for the stability of the oil and for their antioxidant activity. ${ }^{27}$ Therefore, the change in the levels of these compounds is another indication to measure the level of oxidation in olive oil samples. As shown in Figure 6, each sample tested in both the $3^{\text {rd }}$ and $6^{\text {th }}$ months was found to possess a lower chlorophyll amount in comparison with the reference olive oil. On the other hand, the carotenoid levels were also found lower in comparison with the reference product (i.e., Figure 7). In general, chlorophyll and carotenoid levels are expected to be around the 1-3 ppm range. ${ }^{28}$ Therefore, the levels obtained for the sample olive oils definitely showed their lower content in terms of these pigment contents. Besides samples 7, 8, 13, and the reference, the changes in chlorophyll and the carotenoid levels were all found statistically insignificant (i.e., p>0.05). Similar to the results obtained for the TPC of the samples analyzed, this status implies inadequacy in both production conditions and packaging systems, thus making the olive oil products highly susceptible to oxidation. The measurements in total phenol and pigment content of the samples concomitant to statistical analyses are provided in detail in Table 3.

The composition of the fatty acids in the samples tested was measured using a GC method. Table 4 represents the results obtained for the six major fatty acids considered in this study

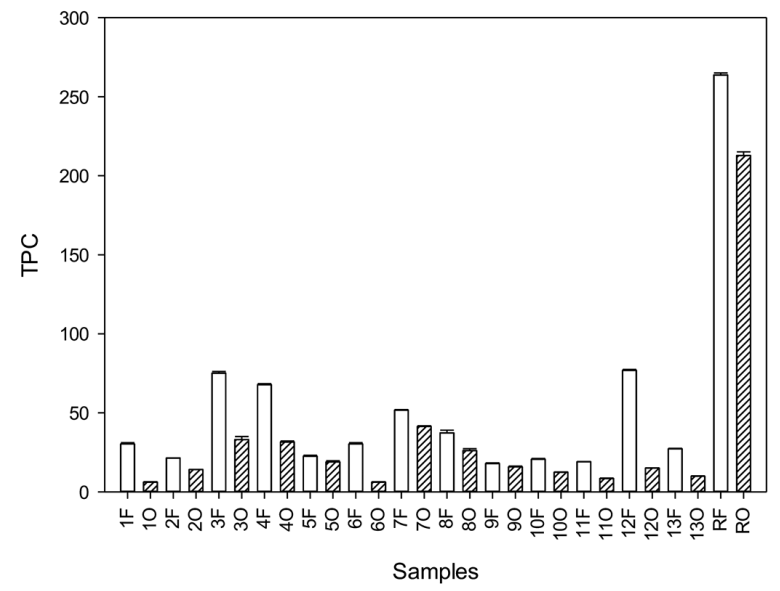

Figure 5. Total phenol content of the samples and reference $F, O$, and $R$ represent 3 months, 6 months, and reference samples, respectively TPC: Total phenol content 
Table 2. Percent free fatty acid, peroxide, and $K_{232}$, and $K_{270}$ measurements

\begin{tabular}{|c|c|c|c|c|c|c|c|c|}
\hline Samples & FFA \% & $\mathrm{p}(\mathrm{FFA})$ & $\mathrm{PV}\left(\mathrm{meqO}_{2} / \mathrm{Kg}\right)$ & $p(P V)$ & $\mathrm{K}_{232}$ & $\mathrm{p}\left(\mathrm{K}_{232}\right)$ & $\mathrm{K}_{270}$ & $\mathrm{p}\left(\mathrm{K}_{270}\right)$ \\
\hline $1 \mathrm{~F}$ & $1.06 \pm 0.07$ & \multirow{2}{*}{$0.009 *$} & $17.66 \pm 0.36$ & \multirow{2}{*}{$0.001^{*}$} & $0.48 \pm 0.02$ & \multirow{2}{*}{$0.005^{\star}$} & $0.08 \pm 0.01$ & \multirow{2}{*}{$0.002^{*}$} \\
\hline 10 & $1.65 \pm 0.08$ & & $28.63 \pm 0.34$ & & $1.29 \pm 0.08$ & & $0.49 \pm 0.02$ & \\
\hline $2 \mathrm{~F}$ & $1.69 \pm 0.04$ & \multirow{2}{*}{$0.008^{*}$} & $15.21 \pm 0.08$ & \multirow{2}{*}{$<0.001^{*}$} & $1.04 \pm 0.03$ & \multirow{2}{*}{$0.002^{\star}$} & $0.16 \pm 0.02$ & \multirow{2}{*}{$0.053^{\star}$} \\
\hline 20 & $2.38 \pm 0.12$ & & $32.60 \pm 0.26$ & & $1.71 \pm 0.02$ & & $0.27 \pm 0.03$ & \\
\hline $3 F$ & $1.19 \pm 0.09$ & \multirow{2}{*}{$0.002^{*}$} & $14.76 \pm 0.27$ & \multirow{2}{*}{$0.004^{*}$} & $0.90 \pm 0.03$ & \multirow{2}{*}{$0.001^{\star}$} & $0.13 \pm 0.02$ & \multirow{2}{*}{$0.002^{*}$} \\
\hline 30 & $2.15 \pm 0.10$ & & $17.37 \pm 0.31$ & & $1.34 \pm 0.05$ & & $0.47 \pm 0.03$ & \\
\hline $4 \mathrm{~F}$ & $1.19 \pm 0.11$ & \multirow{2}{*}{$0.025^{\star}$} & $13.48 \pm 0.36$ & \multirow{2}{*}{$0.003^{\star}$} & $0.95 \pm 0.06$ & \multirow{2}{*}{$-0.003^{*}$} & $0.14 \pm 0.02$ & \multirow{2}{*}{$0.003^{\star}$} \\
\hline 40 & $1.70 \pm 0.05$ & & $22.76 \pm 0.54$ & & $1.48 \pm 0.01$ & & $0.25 \pm 0.02$ & \\
\hline $5 \mathrm{~F}$ & $0.97 \pm 0.06$ & \multirow{2}{*}{$0.011^{\star}$} & $13.90 \pm 0.18$ & \multirow{2}{*}{$0.001^{*}$} & $0.67 \pm 0.01$ & \multirow{2}{*}{$<0.001^{\star}$} & $0.17 \pm 0.02$ & \multirow{2}{*}{0.057} \\
\hline 50 & $1.22 \pm 0.06$ & & $21.81 \pm 0.51$ & & $1.57 \pm 0.02$ & & $0.26 \pm 0.03$ & \\
\hline $6 \mathrm{~F}$ & $1.06 \pm 0.08$ & \multirow{2}{*}{$0.009 *$} & $17.66 \pm 0.36$ & \multirow{2}{*}{$0.001^{*}$} & $0.49 \pm 0.02$ & \multirow{2}{*}{$0.005^{\star}$} & $0.08 \pm 0.01$ & \multirow{2}{*}{$0.002^{*}$} \\
\hline 60 & $1.66 \pm 0.09$ & & $28.63 \pm 0.34$ & & $1.30 \pm 0.08$ & & $0.49 \pm 0.02$ & \\
\hline $7 \mathrm{~F}$ & $1.38 \pm 0.05$ & \multirow{2}{*}{$0.009^{*}$} & $12.47 \pm 0.38$ & \multirow{2}{*}{$<0.001^{*}$} & $0.81 \pm 0.08$ & \multirow{2}{*}{0.054} & $0.16 \pm 0.04$ & \multirow{2}{*}{$0.004^{*}$} \\
\hline 70 & $1.66 \pm 0.06$ & & $28.76 \pm 0.28$ & & $1.08 \pm 0.04$ & & $0.31 \pm 0.02$ & \\
\hline $8 \mathrm{~F}$ & $1.17 \pm 0.02$ & \multirow{2}{*}{$0.001^{*}$} & $13.43 \pm 0.61$ & \multirow{2}{*}{$0.028^{*}$} & $0.85 \pm 0.03$ & & $0.15 \pm 0.02$ & \\
\hline 80 & $1.84 \pm 0.03$ & & $17.16 \pm 0.50$ & & $1.20 \pm 0.08$ & $0.008^{\star}$ & $0.25 \pm 0.02$ & $0.016^{\star}$ \\
\hline $9 \mathrm{~F}$ & $1.53 \pm 0.03$ & $0010 *$ & $12.27 \pm 0.21$ & $0012 *$ & $0.86 \pm 0.05$ & $0 \cap 5$ & $0.23 \pm 0.02$ & 116 \\
\hline 90 & $1.91 \pm 0.10$ & 0.010 & $16.92 \pm 0.79$ & $0.013^{n}$ & $1.19 \pm 0.09$ & 0.054 & $0.29 \pm 0.05$ & 0.140 \\
\hline $10 \mathrm{~F}$ & $1.09 \pm 0.07$ & בחמת & $17.56 \pm 0.28$ & 0 & $0.76 \pm 0.03$ & ? & $0.09 \pm 0.03$ & (חת \\
\hline 100 & $1.43 \pm 0.07$ & 0.003 & $23.50 \pm 0.33$ & 0.003 & $1.37 \pm 0.06$ & 0.003 & $0.25 \pm 0.03$ & 0.004 \\
\hline $11 \mathrm{~F}$ & $1.12 \pm 0.05$ & - & $21.60 \pm 0.20$ & (nת & $1.07 \pm 0.03$ & & $0.15 \pm 0.03$ & \\
\hline 110 & $1.59 \pm 0.06$ & $0.001^{\wedge}$ & $28.20 \pm 0.17$ & $10.001^{\star}$ & $1.64 \pm 0.06$ & $0.002^{\wedge}$ & $0.24 \pm 0.02$ & $0.028^{\wedge}$ \\
\hline $12 \mathrm{~F}$ & $0.92 \pm 0.04$ & . & $8.96 \pm 0.78$ & $\cap \cap 05$ * & $0.81 \pm 0.04$ & 0063 & $0.12 \pm 0.03$ & $<0 \cap 001 *$ \\
\hline 120 & $1.59 \pm 0.05$ & $0.001^{\star}$ & $17.56 \pm 0.30$ & $0.005^{\wedge}$ & $1.56 \pm 0.04$ & 0.063 & $0.22 \pm 0.03$ & 10.001 \\
\hline $13 \mathrm{~F}$ & $1.05 \pm 0.03$ & - $0001 *$ & $10.26 \pm 0.13$ & *2ค月 * & $0.86 \pm 0.03$ & - ค คค २* & $0.12 \pm 0.02$ & • * * * \\
\hline 130 & $1.89 \pm 0.04$ & $0.001^{\wedge}$ & $17.42 \pm 0.45$ & 0.002 & $1.82 \pm 0.08$ & 0.000 & $0.51 \pm 0.04$ & 0.002 \\
\hline Reference F & $0.39 \pm 0.05$ & * & $10.02 \pm 0.20$ & คคคด * & $0.58 \pm 0.03$ & - 0014 * & $0.10 \pm 0.02$ & \\
\hline Reference 0 & $0.66 \pm 0.04$ & $0.02 T^{n}$ & $15.94 \pm 0.15$ & 0.000 & $1.11 \pm 0.09$ & 0.01 & $0.15 \pm 0.02$ & 0.138 \\
\hline
\end{tabular}

F, O, and R represent 3 months, 6 months, and reference samples, respectively.

*: significant if $p<0.05$

[i.e., palmitic acid (C16:0), palmitoleic acid (C16:1), stearic acid (C18:0), oleic acid (C18:1), and linoleic acid (C18:2), and linolenic acid (C18:3)]. First, it is noteworthy that there was a decrease in the fatty acid composition of the samples analyzed from the three to six month analyses, regardless of the fatty acid type. The percentage of oleic acid content of olive oil samples varied from 30 to $46 \%$ both at their $3^{\text {rd }}$ and $6^{\text {th }}$ month analyses (Figure 8). This indicates that none of the samples could be classified as extra virgin olive oil because the IOOC confirms $55-83 \%$ olive oil presence in extra virgin olive oils. ${ }^{20}$ Furthermore, the analysis of other fatty acids also indicated that their ratio was at the lower limits of appreciable amounts, as required by the IOCC. The presence of oxidation as proven via several methods might clearly explain the loss of fatty acids in the samples to oxidation to other ingredients such as polyenes in the first state, and aldehydes and ketone in the second stage. In contrast to the samples, the reference product was shown to possess extra virgin olive oil quality in both the $3^{\text {rd }}$ and $6^{\text {th }}$ month analyses. Besides the change for palmitic acid (C16:0), the rest of the changes for each fatty acid analyzed was found insignificant (i.e., p $>0.05$ ). 
Table 3. Total phenol and pigment content

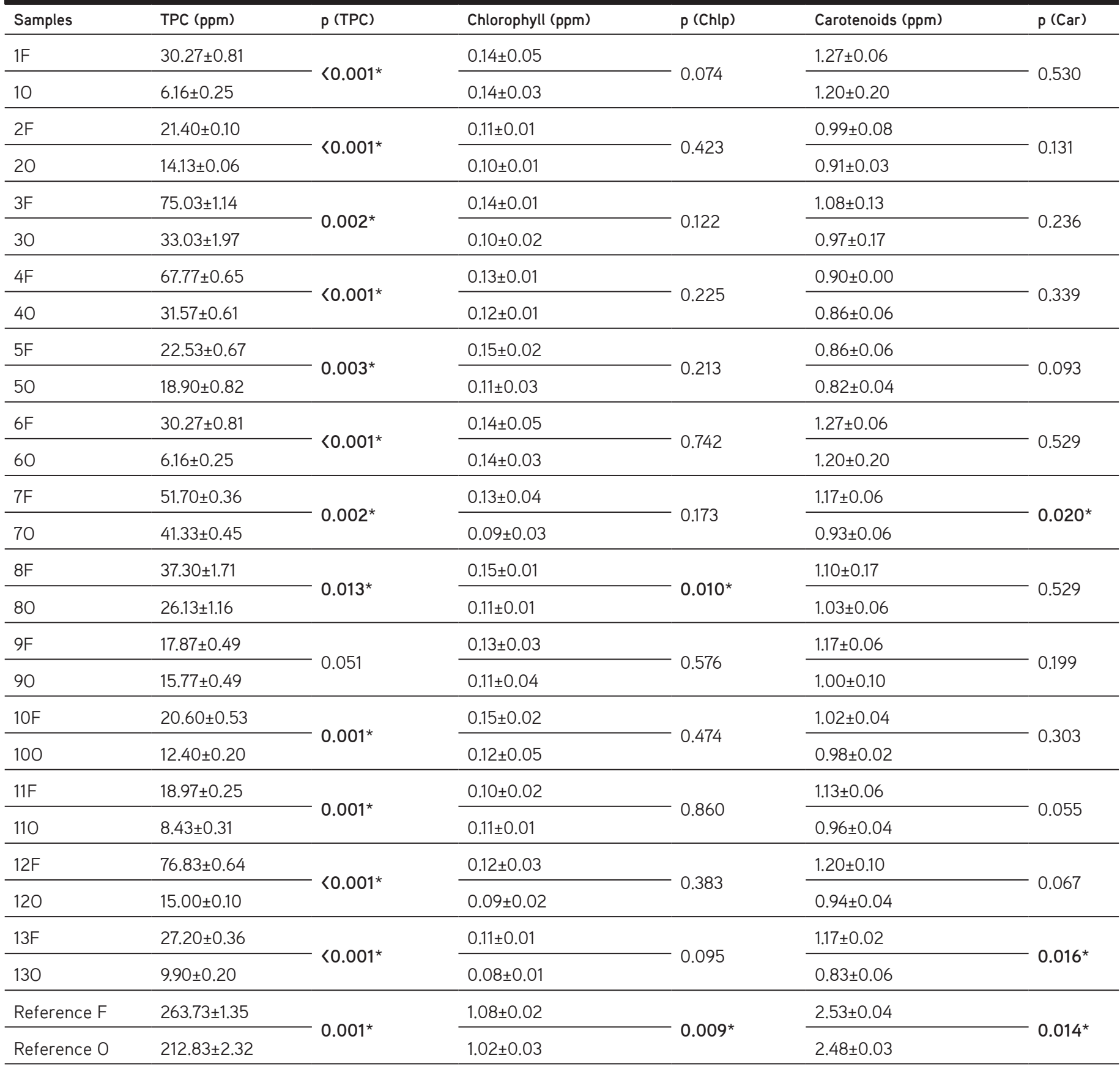

F, O, and R represent 3 months, 6 months, and reference samples, respectively.

*: significant if $p<0.05$

\section{CONCLUSION}

Although olive oil production and consumption is very popular in Northern Cyprus, the quality indices of the oil prepared via traditional methods were found to be low with respect to the results of this study. Indeed, in almost all tests employed, exposure to oxidation was quite unique to these products regardless of the extraction procedure employed (i.e., hot and cold extractions). This absolutely implies inadequacy in production techniques, which may be mainly attributed to insufficient protection against light and air during the production process. Furthermore, the deficiencies regarding the packaging of the oil are another drawback to limit the shelf-life of these products.

This study, known to be conducted for the first time in Northern Cyprus, has highlighted the high oxidation exposure of olive oil produced within the country which employs traditional techniques. Therefore, the results will contribute to the awareness of both producers and consumers. In particular, it will have a significant effect on producers to change their production methods in terms of paying attention to control 


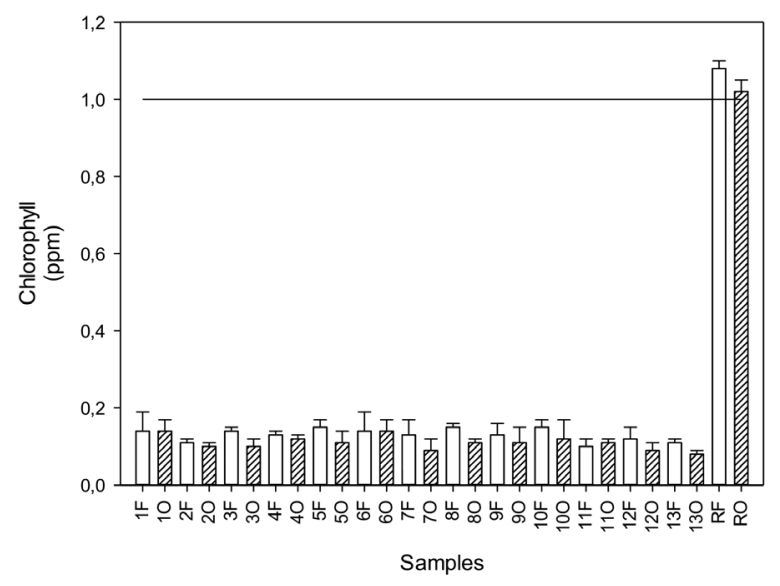

Figure 6. Chlorophyll content of the samples and reference

F, O, and R represent 3 months, 6 months, and reference samples, respectively. The solid line indicates the expected lowest standard for the extra virgin olive oil

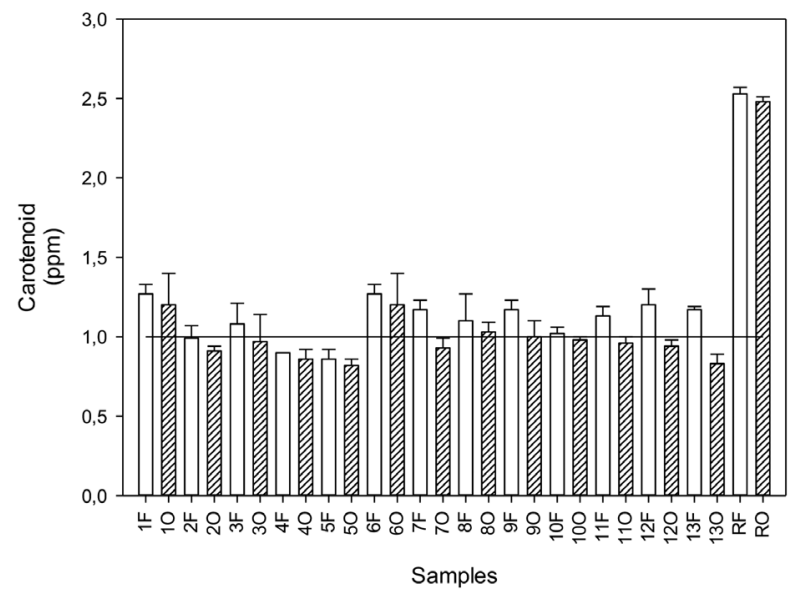

Figure 7. Carotenoid content of the samples and reference

F, O, and R represent 3 months, 6 months, and reference samples, respectively. The solid line indicates the expected lowest standard for the extra virgin olive oil

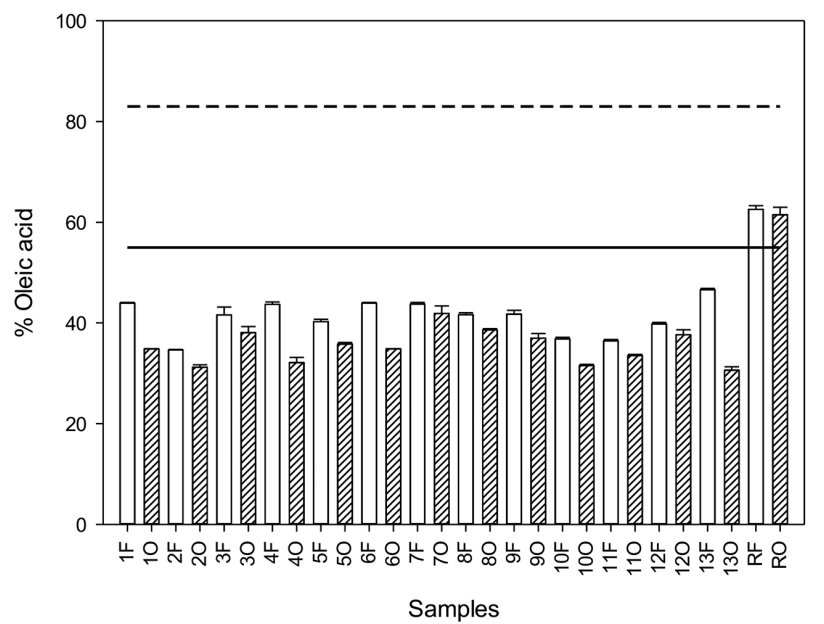

Figure 8. Percent oleic acid of the samples and reference

$F$, O, and R represent 3 months, 6 months, and reference samples, respectively. The solid line, and the dashed lines indicate the standard range for the extra virgin olive oil 


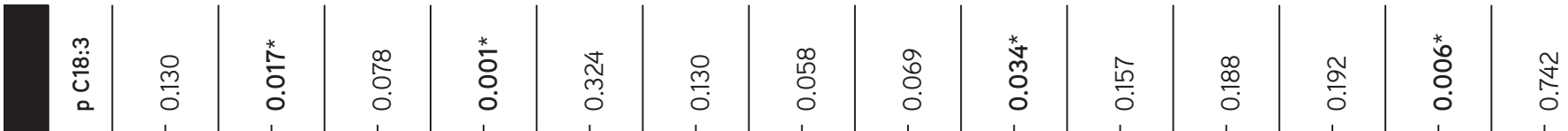

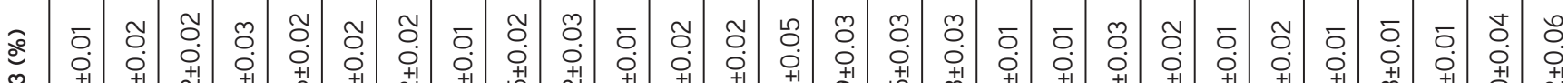

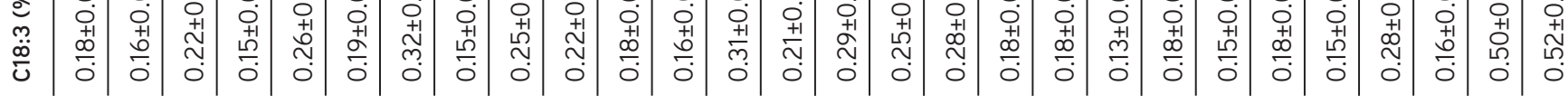

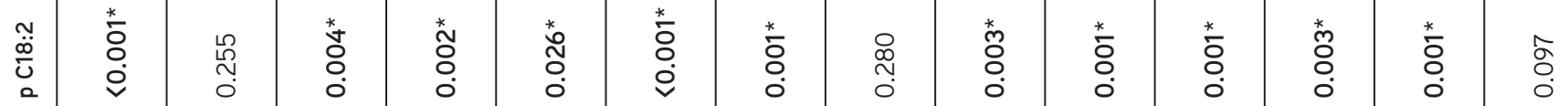

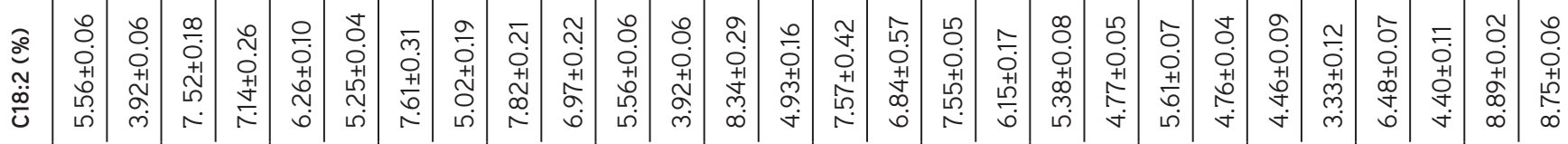

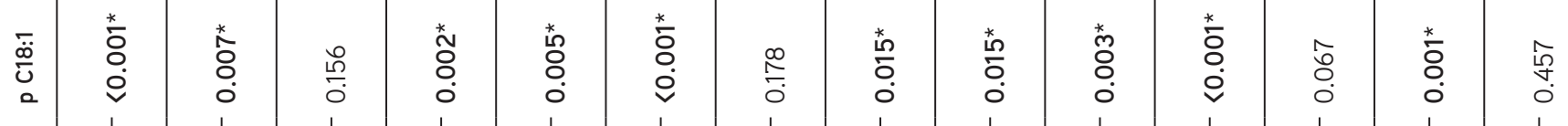

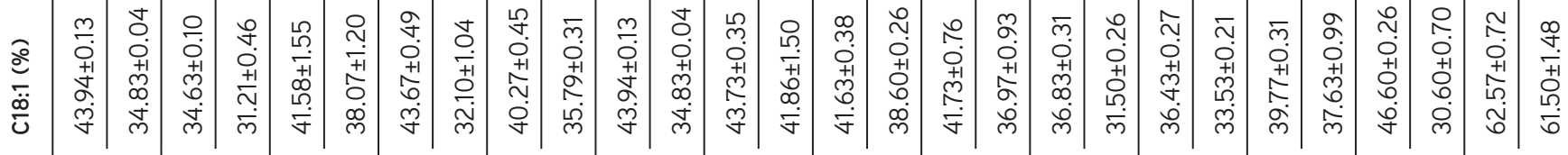

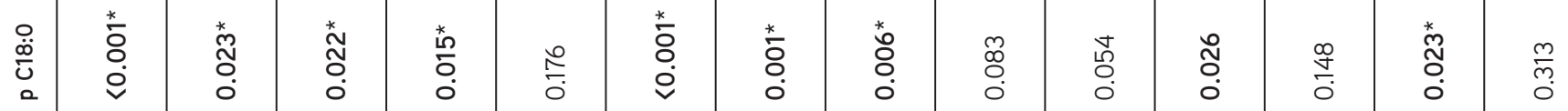
○

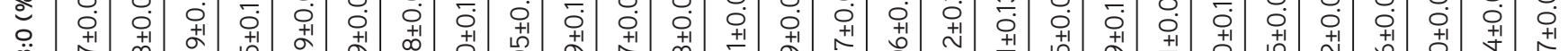

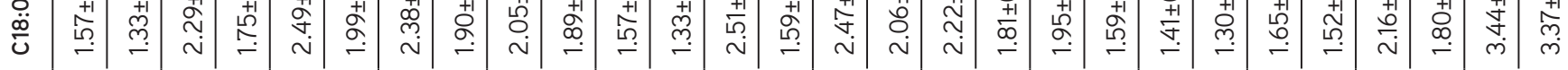

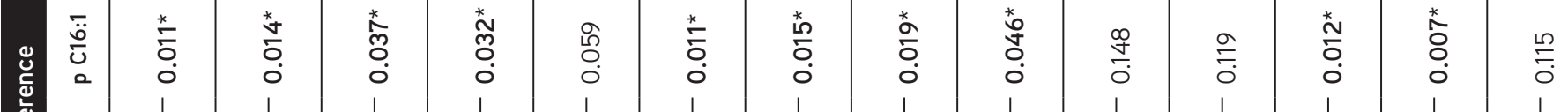

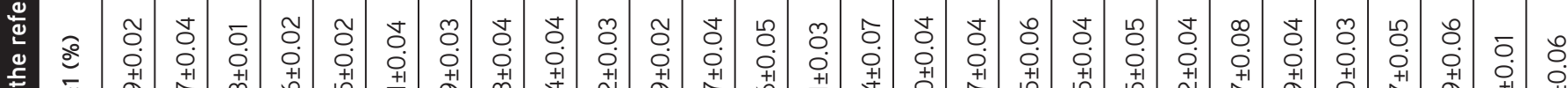

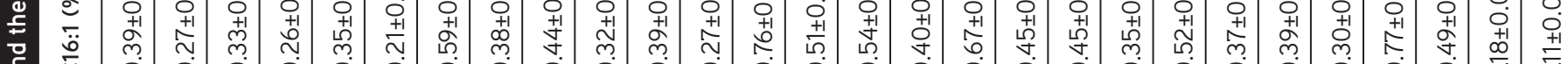

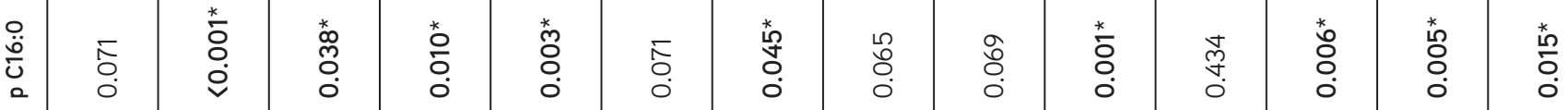

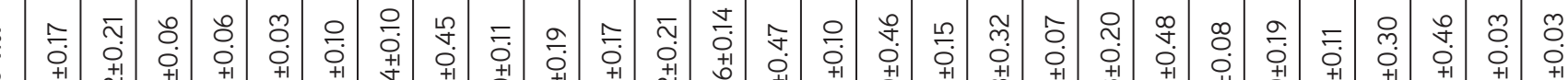

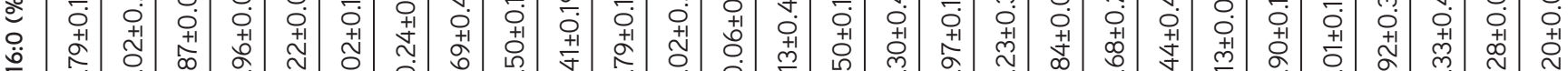

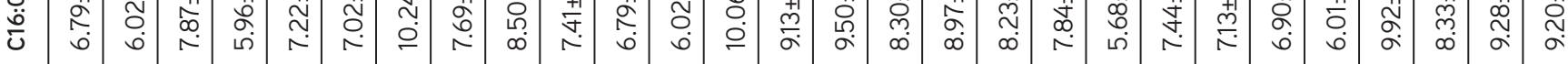

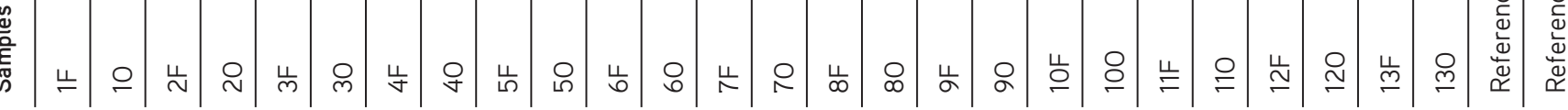

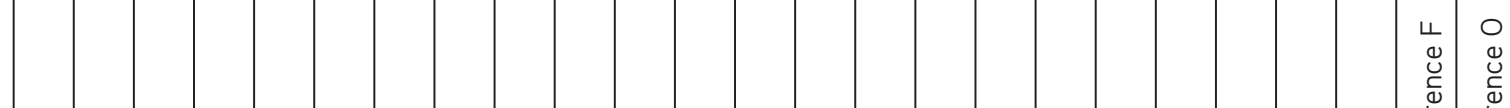


systems (e.g., harvesting and production periods, packaging, and appropriate labeling) to prevent the continuous oxidation in the olive oil produced.

\section{ACKNOWLEDGEMENTS}

This work was supported by Faculty of Pharmacy, Eastern Mediterranean University, research funds.

Conflict of Interest: No conflict of interest was declared by the authors.

\section{REFERENCES}

1. Willett WC, Sacks F, Trichopoulou A, Drescher G, Ferro-Luzzi A, Helsing E, Trichopoulos D. Meditaerrenean diet pyramid. A cultural model for healthy eating. Am J Clin Nutr. 1995;61(Suppl 6):1402-1406.

2. Trichopoulou A, Lagiou P. Healthy traditional Mediterranean diet: an expression of culture, history, and lifestyle. Nutr Rev. 1997;55:383-389.

3. Vossen P. Olive Oil: History, Production, and Characteristics of the World's Classic Oils. HortScience. 2007;42:1093-1100.

4. Luchetti F. Importance and future of olive oil in the world market - an introduction to olive oil. Eur J Lipid Sci Technol. 2002;104:559-563.

5. Dais P, Hatzakis E. Quality assessment and authentication of virgin olive oil by NMR spectroscopy: a critical review. Anal Chim Acta. 2013;26:1-27.

6. Lopez CP, Rodriguez AH, Camona C, Torres S, Sayadi S. ISO 9001 implementation and associated manufacturing and marketing practices in the olive oil industry in southern Spain. Food Control. 2016;62:23-31.

7. International Olive Council Documents, T. OT/Doc. no. 2-4, 2006, Quality management guide for the olive oil industry: Olive Oil Mills., Available at: http://www.internationaloliveoil.org/estaticos/view/222-standards.

8. http://www.aboutcyprus.org.cy/en/the-olive-tree-and-olive-oil-in-thetraditional-life-of-cyprus

9. Economic analysis of the olive sector, European Commission, Directorate-General for Agriculture and Rural Development, Available at: http://ec.europa.eu/agriculture/olive-oil/economic-analysis_en.pdf.

10. Avraamides A, Fatta D. Resource consumption and emissions from olive oil production: a life cycle inventory case study in Cyprus. Journal of Cleaner Production. 2008;16:809-821.

11. Kalogeropoulosa N, Kalioraa AC, Artemioua A, Giogiosa I. Composition, volatile profiles and functional properties of virgin olive oils produced by two-phase vs three-phase centrifugal decanters. LWT Food Sci Tech. 2014;58:272-279.

12. Plaza M, Turner C. Pressurized hot water extraction of bioactives. Trac Trends in Anal Chem. 2015;71:39-54.

13. Sinesioa F, Monetaa E, Raffoa A, Lucchettia S, Peparaioa M, D'Aloiseb A, Pastorea G. Effect of extraction conditions and storage time on the sensory profile of monovarietal extra virgin olive oil (cv Carboncella) and chemical drivers of sensory changes. LWT Food Sci Tech. 2015;63:281288.
14. ISO660:2009, Animal and vegetable fats and oils. Determination of acid value and acidity, available at: https://www.iso.org/obp/ ui/\#iso:std:iso:660:ed-3:v1:en

15. ISO 3960:2007, Animal and vegetable fats and oils. Determination of peroxide value -- lodometric (visual) endpoint determination, Available at: http://www.iso.org/iso/catalogue_detail.htm?csnumber=39158

16. European Official Method of Analysis (Commision Regulation EEC $\mathrm{N}-2568 / 91$ on the characteristics of olive oil and olive-residue oil and on the relevant methods of analysis), Available at: http://eur-lex.europa.eu/ legal-content/en/ALL/?uri=CELEX:31991R2568

17. Mosquera MIM, Navarro MLR, Rojas BG, Sanchez Gomez AH, Fernandez JG. Color-pigment correlation in virgin olive oil. Journal of the American Oil Chemists Society. 1991;68:332-336.

18. Montedoro G, Servili MM, Baldioli M, Miniati E. Simple and hydrolyzable phenolic compounds in virgin olive oil. 1. Their extraction, separation, and quantitative and semiquantitative evaluation by HPLC. J Agric Food Chem. 1992;40:1571-1576.

19. Commission implementing regulation (EU) No 1348/2013 amending Regulation (EEC) No 2568/91 on the characteristics of olive oil and oliveresidue oil and on the relevant methods of analysis, Available at: https:// www.fsai.ie/uploadedFiles/Reg1348_2013.pdf

20. Designations and definitions of olive oils characterized by IOOC, Available at: http://www.internationaloliveoil.org/web/aa-ingles/oliveWorld/aceite1.html

21. Vekiari SA, Papadopouloua P, Koutsaftakisb A. Comparison of different olive oil extraction systems and the effect of storage conditions on the quality of the virgin olive oil. Grasas y Aceite. 2002;53:324-329.

22. Kiritsakis AK. Flavour components of olive oil--A review. Journal of the American Oil Chemists' Society. 1998;75:673-681.

23. Kritsakis A, Kanavouras A, Kritsakis K. Chemical analysis, quality control and packaging issues of olive oil. European Journal of Lipid Science and Technology. 2002;104:628-638.

24. Gaye Y. Effect of storage time on olive oil quality. Thesis Submitted to The Graduate School of Engineering and Sciences of İzmir Institute, 2009, Available at: http://library.iyte.edu.tr/tezler/master/gidamuh/ T000800.pdf

25. Bendini A, Cerretani L, Carrasco-Pancorbo A, Gómez- Caravaca AM, Segura-Carretero A, Fernández-Gutiérrez A, Lercker G. Phenolic Molecules in Virgin Olive Oils: a Survey of Their Sensory Properties, Health Effects, Antioxidant Activity and Analytical Methods. An Overview of the Last Decade. Molecules. 2007;12:1679-1719.

26. Amiot MJ, Fleuriet A, Macheix JJ. Importance and evolution of phenolic compounds in olive during growth and maturation. J Agric Food Chem. 1986;34:823-826.

27. Zegane O, Keciri S, Louaileche H. Physicochemical Characteristics and Pigment Content of Algerian Olive Oils: Effect of Olive Cultivar and Geographical Origin. International Journal of Chemical and Biomolecular Science. 2015;1:153-157.

28. Ruiza RA, Rojasb BG. Decoloration kinetics of chlorophylls and carotenoids in virgin olive oil by autoxidation. Food Research International. 2014;65:199-206. 